\title{
Resistance to anti-PD-1-based immunotherapy in basal cell carcinoma: a case report and review of the literature
}

\author{
Francesco Sabbatino ${ }^{1 *}$, Antonio Marra², Luigi Liguori ${ }^{1}$, Giosuè Scognamiglio ${ }^{3}$, Celeste Fusciello ${ }^{1}$, Gerardo Botti ${ }^{3}$, \\ Soldano Ferrone ${ }^{4}$ and Stefano Pepe ${ }^{1}$
}

\begin{abstract}
Background: Immunotherapy with immune checkpoint inhibitors has radically changed the management of a broad spectrum of tumors. In contrast, only very limited information is available about the efficacy of these therapies in non-melanoma skin cancers, especially in basal cell carcinoma. The latter malignancy is often associated with both an impairment of the host immune response and a high mutation burden, suggesting that immune checkpoint inhibitor-based immunotherapy may be effective in the treatment of this tumor.

Case presentation: A 78-year-old woman was diagnosed with a metastatic non-small-cell-lung-cancer. Following the lack of response to two lines of systemic chemotherapy, she was treated with the anti-PD-1 monoclonal antibody nivolumab, obtaining a prolonged stable disease. Under nivolumab treatment, the patient developed a basal cell carcinoma of the nose. The latter was surgically resected. Immunohistochemical staining of tumor tissue showed a PD-L1 expression < 1\% and lack of human leukocyte antigen class I subunit (i.e. heavy and light chain) expression on tumor cells. In addition, a limited number of T cells (CD3+) was present in the tumor microenvironment, with a higher number of regulatory $T$ cells (Foxp3+) and macrophages $(\mathrm{Cd} 11 \mathrm{~b}+)$ as compared to a low infiltration of activated cytotoxic T cells (CD8+/ Granzyme B+). Two months following the surgical removal of the tumor, while still on nivolumab treatment, the patient relapsed with a basal cell carcinoma in the same anatomic site of the previous surgical excision. The tumor displayed the same pathological characteristics.

Conclusion: Preclinical lines of evidence suggest a potential role of immune checkpoint inhibitors for basal cell carcinoma treatment. However, limited clinical data is available. In the patient we have described administration of the immune checkpoint inhibitor nivolumab for the treatment of a responsive non-small cell carcinoma was associated with the development and relapse of a basal cell carcinoma tumor. This association is likely to reflect the resistance of basal cell carcinoma cells to anti-PD-1 based immunotherapy because of a "cold" tumor microenvironment characterized by lack of human leukocyte antigen class I expression, low PD-L1 expression and high number of immune regulatory cells.
\end{abstract}

Keywords: Basal cell carcinoma, Immunotherapy, PD-1, PD-L1, HLA class I antigens, $\beta 2$-microglobulin, Immune escape, Regulatory immune cells, T cell infiltration, Nivolumab

\footnotetext{
* Correspondence: fsabbatino@unisa.it

${ }^{1}$ Medical Oncology Unit, Department of Medicine, Surgery and Dentistry,

University of Salerno, 84131 Salerno, Italy

Full list of author information is available at the end of the article
}

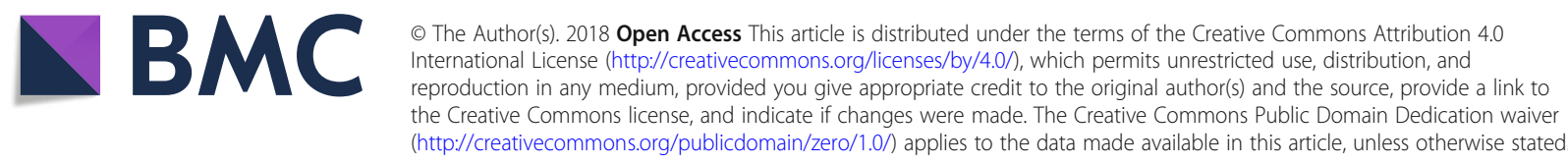




\section{Background}

Basal cell carcinoma (BCC) is the most common human cancer, accounting for about $25 \%$ of all diagnosed tumors worldwide $[1,2]$. Although BCC can be often controlled by radical surgery, it can present aggressive features such as local recurrence, tissue destruction and in a small percentage of cases widespread dissemination $[3,4]$. A deeper knowledge of the mechanisms underlying $\mathrm{BCC}$ development and progression has allowed the discovery of mutations in the sonic hedgehog homolog (SHH) pathway as the most common oncogenic alterations $[5,6]$. These observations have led to the use of small molecules targeting the SHH pathway such as vismodegib and sonidegib, both currently approved for the treatment of recurrent or metastatic BCC [7-9]. However, the efficacy of these agents is limited due to the progressive development of drug resistance $[10,11] \mathrm{em}-$ phasizing the need to develop novel therapeutic agents. Recently, immune checkpoint inhibitors (ICIs) such as anti-programmed death-1 (PD-1)- and -programmed death-ligand 1 (PD-L1) monoclonal antibodies (mAbs) have markedly changed the treatment of several types of cancer, significantly improving patient survival and quality-of-life [12]. For example, in non-small-cell lung cancer (NSCLC), ICIs have shown to be effective in first and advanced lines of the metastatic setting [13] as well as in the locally advanced NSCLC improving the overall response rate (ORR), progression-free survival (PFS) and overall survival (OS) of treated patients as compared to standard chemotherapy [14-21]. In contrast ICIs are still in the early stages of clinical assessment for treating BCCs and limited clinical evidence is at present available about their therapeutic efficacy [22-26]. Furthermore ICI-based immunotherapy is effective only in a small subset of cancer patients and no clear predictive biomarker of response has been identified so far.

Here, first, we will describe a patient who developed a BCC during treatment of metastatic NSCLC with the anti PD-1 mAb nivolumab. Second, we will analyze and describe the potential mechanisms of tumor immune escape developed by BCC cells that are associated with lack of $\mathrm{BCC}$ response to nivolumab. Lastly we will discuss the most relevant lines of clinical evidence utilizing ICIs for the treatment of $\mathrm{BCC}$ patients and the predictive biomarkers identified in order to select $\mathrm{BCC}$ patients who are more likely to benefit from this type of therapy.

\section{Case presentation}

In October 2013, a 78-year-old woman was admitted to our Oncology Unit because of the development of costal pain and cough. A chest CT-scan showed a complete atelectasis of the left lung inferior lobe, a solitary nodule in apex segment of the upper right lung lobe, the presence of multiple small nodules in basal posterior segments of the right lung lobe as well as in the middle and upper left lung lobes, and a left pleural effusion (Fig. 1a). She had a good performance status (PS) (ECOG PS $=0$ ). Her prior medical history was remarkable for surgical excisions of two nodular BCCs of the trunk $(0.5 \times 0.3 \mathrm{~cm}$ and $0.6 \times 0.7 \mathrm{~cm}$, respectively, both without perivascular and perineural invasion) in 2003. In addition, she was an active smoker ( 40 packs/year).

In order to complete the pathological and clinical staging, the patient received a whole-body ${ }^{18} \mathrm{FDG}$-PET/CT and a bronchoscopy with a biopsy of the left lung lesion. The ${ }^{18}$ FDG-PET/CT showed a high metabolic activity of the lesion in the left lung, whereas the other lesions did not show any metabolic activity. The pathological examination
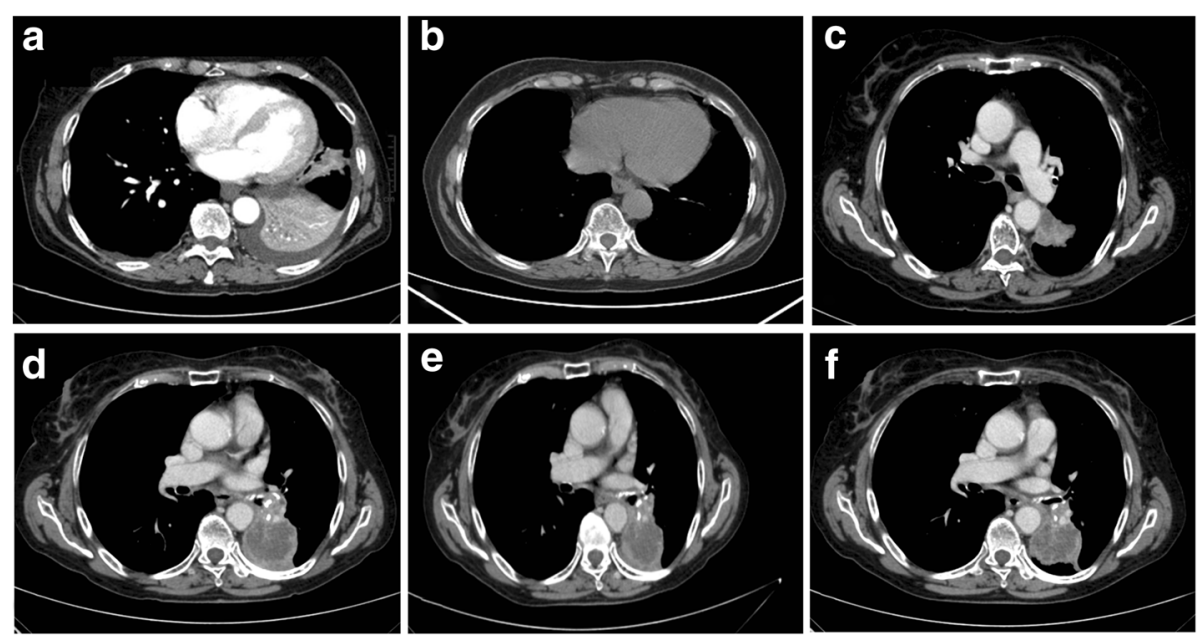

Fig. 1 Chest CT-scan performed at diagnosis in October 2013 (a), in May 2014 following first line chemotherapy (b), in April 2015 at tumor progression following radiotherapy (c), in January 2016 before starting immunotherapy (d), in May 2016 during immunotherapy (e) and in December 2017 following 38 cycles of immunotherapy administration (f) 
demonstrated the diagnosis of lung squamous cell carcinoma (p63+, TTF-1-). She was staged as a stage IV NSCLC (according to TNM staging 7th edition).

Because of her good clinical conditions, the patient was treated with six cycles of chemotherapy with gemcitabine $\left(1250 \mathrm{mg} / \mathrm{m}^{2}\right)$, on days 1 and 8 , plus cisplatin $\left(75 \mathrm{mg} / \mathrm{m}^{2}\right)$ on day 8 , every 21 days. In May 2014, whole-body CT scan showed a partial response (PR) (according to RECIST 1.1 criteria) following six cycles of chemotherapy with $90 \%$ reduction of the hilar lesion and disappearance of the pleural effusion (Fig. 1b). Following multidisciplinary discussion, the patient received a consolidative radiotherapy treatment on the residual disease, obtaining a stable disease (SD) for an additional 8 months. However, in April 2015, a whole-body CT scan showed a progression of disease (PD) with an increased diameter of the left hilar lesion and the appearance of several hilar lymph nodes (Fig. 1c). Thus the patient received a secondline chemotherapy with 6 cycles of docetaxel $\left(75 \mathrm{mg} / \mathrm{m}^{2}\right)$ every 21 days, obtaining a SD. Unfortunately, in January 2016, a whole-body CT scan showed a PD with an increase of the pulmonary hilar lesion associated with atelectasis of the inferior left lobar bronchus and several pathological mediastinal lymph nodes (Fig. 1d). In order to reanalyze tumor histology and the molecular profile, we decided to perform a re-biopsy of the left lung lesion. Pathological examination confirmed the diagnosis of lung squamous cell carcinoma. No targetable oncogenic alterations (EGFR mutations, ALK/ROS-1 rearrangements and BRAF mutations) were detected. PD-L1 expression on tumor cells was scored as $>1 \%$ on tumor proportional score (TPS).

Based on these results, we decided to start a third-line treatment with the anti-PD-1 mAb nivolumab at the dose of $3 \mathrm{mg} / \mathrm{kg}$, every 14 days. In February 2016, the patient started the administration of nivolumab. In May 2016, a CT scan showed a SD (Fig. 1e) which was confirmed in successive restaging of the disease (Fig. 1f).
Following 18 cycles of nivolumab treatment (in January 2017), in a good performance status and without experience of any immune-related adverse event, the patient developed an ulcerated lesion $($ diameter $=1.0 \times 1.4 \mathrm{~cm})$ localized at the right ala of nose (Fig. 2a). While she was on nivolumab treatment, in February 2017, she underwent an excisional skin biopsy. Histological examination of the lesion showed an ulcerated nodular BCC. Perivascular and perineural invasions were not detected. Surgical tumor margins were negative. Immunohistochemical (IHC) staining of tumor showed a PD-L1 expression < $1 \%$, on both tumor cells and immune cells, and lack of human leukocyte antigen (HLA) class I and $\beta 2$-microglobulin $(\beta 2 \mathrm{~m})$ expression on tumor cells (Fig. 3). In addition, a limited number of $\mathrm{T}$ cells $(\mathrm{CD} 3+)$ was present in the tumor microenvironment, with a higher number of regulatory $\mathrm{T}$ cells (Foxp3+) and macrophages $(\mathrm{CD} 11 \mathrm{~b}+)$ as compared to activated cytotoxic T cells (CD8+/ Granzyme B+) (Fig. 3). After two months, while still being treated with nivolumab, the patient relapsed with a new BCC lesion in the same region of the previous surgical excision (Fig. 2b). A new surgical excision was performed and the pathological examination confirmed the diagnosis of a relapsed BCC with same pathological characteristics.

At present, the patient is still being treated with nivolumab. She has received 46 cycles of nivolumab. Sustained stable disease control is still ongoing for metastatic NSCLC. She is in good health conditions. No treatment-related toxicities have been observed. No additional BCC relapses have been detected so far.

\section{Discussion}

Over the last ten years, the implementation of ICI-based immunotherapy has been one of the major breakthroughs for the treatment of cancer patients. Several mAbs targeting immune checkpoint molecules such as Cytotoxic T Lymphocyte Antigen-4 (CTLA-4), PD-1 and PD-L1 have been approved for the treatment of a broad
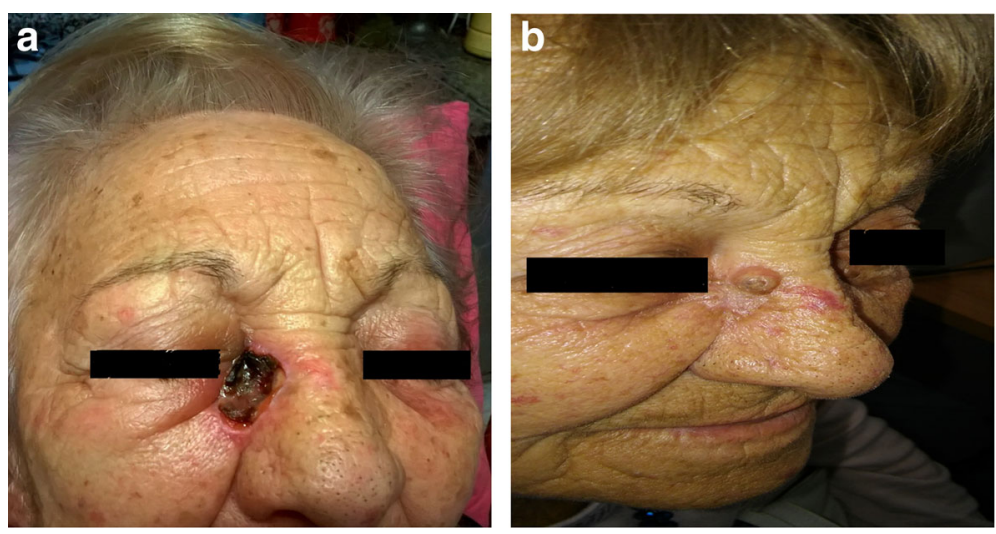

Fig. 2 a Primary BCC developed by the patient during nivolumab treatment. b BCC relapse after surgery 


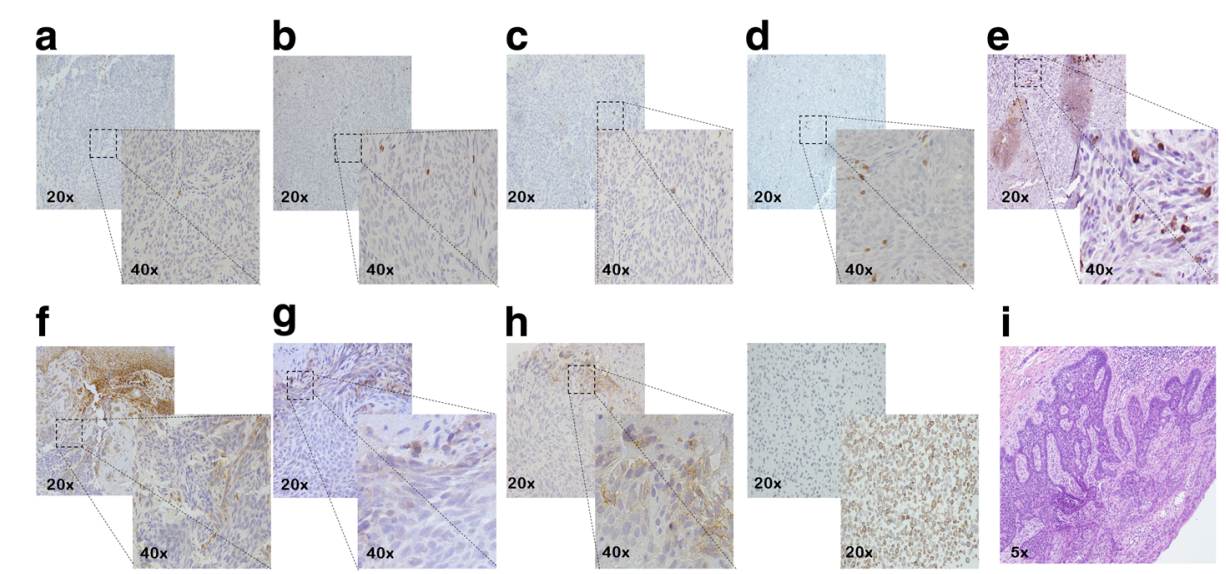

Fig. 3 Representative staining patterns of the formalin-fixed, paraffin-embedded primary BCC lesion with granzyme-B (a), FOXP3 (b), CD8 (c), CD3 (d) and CD11b (e) specific mAbs. Number of positive cells were enumerated in an entire lesion and reported as an absolute number. $\mathbf{f}$ Representative staining patterns of the formalin-fixed, paraffin-embedded primary BCC lesion with HLA class I antigen-specific mAbs. Tumor tissue sections were immunohistochemically (IHC) stained with a pool of mouse HLA-A-specific mAb HCA2 and HLA-B/C-specific mAb HC10 (ratio, 1:1). mAb HCA2 recognizes $\beta 2$ m-free HLA-A (excluding -A24), -B7301, and -G heavy chains; $m A b$ HC10 recognizes $\beta 2 m$-free HLA-A3, $-A 10,-A 28,-A 29,-A 30,-A 31$, -A32, -A33, and all $\beta 2 \mathrm{~m}$-free -HLA-B (excluding -B5702, -B5804, and -B73) and -HLA-C heavy chains [53-55]. IHC staining was performed as described previously [56]. Staining of infiltrating immune cells was used as an internal positive control. The staining with HLA class I antigen-specific mAbs on tumor cells was scored as negative because HLA class I antigen score in an entire lesion was $0 . \mathbf{g}$ Representative staining patterns of the formalin-fixed, paraffin-embedded primary BCC lesion with $\beta 2 \mathrm{~m}$-specific mAb NAMB-1 [57]. IHC staining was performed as described previously [56]. Staining of infiltrating immune cells or fibroblasts was used as an internal positive control. The staining with $\beta 2 \mathrm{~m}$-specific mAb on tumor cells was scored as negative because $\beta 2 \mathrm{~m}$ score in an entire lesion was 0 . $\mathbf{h}$ Representative staining patterns of the formalin-fixed, paraffin-embedded primary BCC lesion with PD-L1-specific mAb (left panel). PD-L1 IHC staining was performed utilizing the automated PD-L1 IHC assay (PD-L1 IHC 28-8 pharmDx SK005) with Dako's Autostainer Link 48 [58]. This test is a complementary diagnostic for nivolumab. MCF7 and NCl-H226 cell lines were used as a negative (upper and right panel) and positive control (bottom and right panel), respectively, accordingly to manufacturer kit instructions. PD-L1 expression was scored as negative because PD-L1 score in an entire lesion was $<1 \%$, both on tumor cells and immune cells. Slides were reviewed and enumerated by an experienced pathologist (GB). i Representative staining patterns of the formalin-fixed, paraffin-embedded primary BCC lesion with hematoxylin and eosin (H\&E). Magnification is indicated

spectrum of cancers [12]. ICIs are also currently being investigated for patients with relapsed-recurrent or metastatic BCC (Table 1). However the clinical efficacy of ICIs is limited to a small percentage of treated patients. The identification of predictive biomarkers of response to ICIs represents at present one of the major challenges in cancer research [27, 28]. PD-L1 expression has been the most explored predictive biomarker so far. Several studies have shown a significant correlation between PD-L1 expression in the tumor microenvironment and an increased likelihood of response to anti-PD-1/PD-L1 therapy [19, 29]. In contrast, many other studies have also shown that patients who do not express PD-L1 in the tumor microenvironment may also benefit from anti-PD-1/PD-L1-based immunotherapy [14-18]. Overall, PD-L1 is considered a "surrogate" biomarker that can be used to predict patients who are more likely to benefit from anti-PD-1/PD-L1 immunotherapy. In the patient we have described administration of nivolumab for the treatment of a responsive NSCLC was associated with the development and relapse of a BCC tumor. Several lines of evidence have highlighted the critical role of immune surveillance in the control of $\mathrm{BCC}$, as demonstrated by the increased incidence of these tumors in immunosuppressed subjects [30,31].
In order to identify the potential mechanisms underlying nivolumab inability to control BCC development, we analyzed the expression of PD-L1 in both the primary and the relapsed tumor. Conflicting data about PD-L1 expression in $\mathrm{BCC}$ has been reported in the literature so far. Chang et al. analyzed 138 BCCs showing a PD-L1 expression on tumor cells and tumor infiltrating lymphocytes (TILs) of 89.9 and $94.9 \%$, respectively. More importantly, PD-L1 expression was higher in previously treated patients as compared to treatment-naïve subjects [32]. In contrast, Lipson et al. analyzed $40 \mathrm{BCCs}$ and showed a PD-L1 expression on tumor cells and TILs of 22.0 and $82.0 \%$, respectively [23]. The same authors also described a previously-treated BCC patient who carried a tumor with a high PD-L1 expression. The patient was treated with the anti-PD-1 mAb pembrolizumab and obtained a prolonged PR [23]. Similar results have been reported by Falchook et al. [24] and by Winkler et al. [33]. The latter investigators showed that a metastatic BCC patient obtained a SD following pembrolizumab administration [33]. The former investigators reported that a previously-treated BCC patient obtained a partial response that lasted more than 12 months following treatment with the anti-PD-1 mAb cemiplimab [24]. 
Table 1 Ongoing clinical trials testing immunotherapeutic agents in BCC patients

\begin{tabular}{|c|c|c|c|c|c|}
\hline Agent & Phase & Condition & Intervention & Status & ClinicalTrials.gov ID \\
\hline \multirow[t]{4}{*}{ Talimogene Laherparepvec } & \multirow[t]{4}{*}{ I } & Non-melanoma Skin Cancer & \multirow{4}{*}{$\begin{array}{l}\text { Evaluation of the mechanism of action } \\
\text { of talimogene laherparepvec (T-VEC) } \\
\text { in patients with locally advanced } \\
\text { non-melanoma skin cancer }\end{array}$} & \multirow[t]{4}{*}{ Not yet recruiting } & \multirow[t]{4}{*}{ NCT03458117 } \\
\hline & & Basal Cell Carcinoma & & & \\
\hline & & $\begin{array}{l}\text { Squamous Cell Carcinoma } \\
\text { Cutaneous Lymphoma }\end{array}$ & & & \\
\hline & & Merkel Cell Carcinoma & & & \\
\hline ASN-002 & $|/| \mid$ & $\begin{array}{l}\text { Basal Cell Carcinoma in } \\
\text { Basal Cell Nevus Syndrome }\end{array}$ & $\begin{array}{l}\text { Study of ASN-002 to Treat Basal Cell } \\
\text { Carcinomas in Individuals with Basal } \\
\text { Cell Nevus Syndrome }\end{array}$ & Not yet recruiting & NCT03208296 \\
\hline REGN2810 & $\|$ & Basal Cell Carcinoma & $\begin{array}{l}\text { Anti-PD-1 in Patients with Advanced } \\
\text { Basal Cell Carcinoma Who Experienced } \\
\text { Progression of Disease on Hedgehog } \\
\text { Pathway Inhibitor Therapy, or Were } \\
\text { Intolerant of Prior Hedgehog Pathway } \\
\text { Inhibitor Therapy }\end{array}$ & Recruiting & NCT03132636 \\
\hline $\begin{array}{l}\text { Nivolumab + Talimogene } \\
\text { Laherparepvec }\end{array}$ & $\|$ & $\begin{array}{l}\text { Refractory Lymphomas } \\
\text { Advanced or Refractory } \\
\text { Non-melanoma Skin Cancers }\end{array}$ & $\begin{array}{l}\text { Talimogene Laherparepvec and } \\
\text { Nivolumab in Treating Patients with } \\
\text { Refractory Lymphomas or Advanced } \\
\text { or Refractory Non-melanoma Skin } \\
\text { Cancers }\end{array}$ & Recruiting & NCT02978625 \\
\hline $\begin{array}{l}\text { Pembrolizumab +/- } \\
\text { Vismodegib }\end{array}$ & $\|$ & Skin Basal Cell Carcinoma & $\begin{array}{l}\text { Pembrolizumab With or Without } \\
\text { Vismodegib in Treating Metastatic or } \\
\text { Unresectable Basal Cell } \\
\text { Skin Cancer }\end{array}$ & $\begin{array}{l}\text { Active, not } \\
\text { recruiting }\end{array}$ & NCT02690948 \\
\hline ASN-002 +/- 5-FU & $|/| \mid$ & $\begin{array}{l}\text { Basal Cell Nevus Syndrome } \\
\text { Skin Neoplasm Nodular } \\
\text { Basal Cell Carcinoma of Skin }\end{array}$ & $\begin{array}{l}\text { A Study of the Efficacy and Safety of } \\
\text { ASN-002 in Adult Patients with } \\
\text { Low-risk Nodular Basal Cell } \\
\text { Carcinoma }\end{array}$ & Recruiting & NCT02550678 \\
\hline
\end{tabular}

In the latter two patients, PD-L1 expression was non-detectable [24] or low [33]. Our treatment-naïve $\mathrm{BCC}$ patient, who expressed PD-L1 on $<1 \%$ of both tumor cells and TILs, did not respond to anti-PD-1 immunotherapy. These conflicting results most likely reflect the different mAbs used to detect PD-L1 expression and the PD-L1 cut-off adopted, and/or the different characteristics of the BCC tumors in the three patients investigated.

Besides PD-L1, other predictive biomarkers for ICIs have been investigated or are currently under evaluation. Among all tested markers, the presence of a high tumor mutational burden (TMB) has been strongly correlated with clinical responses in patients treated with ICIs [34-37]. TMB is a measurement of the number of nonsynonymous mutations carried by tumor cells. Mutations cause an increased expression of neoantigens in the context of HLA class I antigens enhancing the recognition of cancer cells by cognate $\mathrm{T}$ cells. This event is crucial for the development of a host immune response and consequently for ICI efficacy [38]. Therefore a high-TMB is expected to identify patients who are more likely to benefit from ICI-based immunotherapy because of the increased recognition and successive destruction of tumor cells by cognate T cells unleashed by ICIs. Nevertheless, also patients with a high-TMB cancer may not respond to ICIs [38] questioning its role as a predictive biomarker. BCCs are reported to carry a high
TMB (65 mutations/Mb), most likely due to the UV signature [39]. In a recent study, Goodman et al. showed that the median TMB for 9 BCC samples and 1637 samples from other type of malignancies was $90 / \mathrm{Mb}$ and $4 / \mathrm{Mb}$, respectively [26]. In addition, in two BCCs, Ikeda et al. showed the presence of amplification of the 9p24.3-9p22.2 region which contains the PD-L1, PD-L2 and JAK2 genes [22]. Of interest, PD-L1, PD-L2 and JAK2 amplification is a characteristic of Hodgkin lymphoma, which is exquisitely sensitive to nivolumab [40-42]. Noteworthy, three out of four BCC patients treated with nivolumab presented an objective and durable tumor response [22, 26]. In the patient we have described, we did not investigate the TMB or presence of amplification of the 9p24.39p22.2 region. Conversely, we focused our studies on immune cell infiltrate as well as on HLA class I antigen and $\beta 2-\mathrm{m}$ expression by tumor cells. Both lack of HLA class I antigen expression and low number of activated cytotoxic T cells (CD8+/ Granzyme B+) can justify the lack of a clinical response to nivolumab. Indeed, HLA class I antigen down-regulation is associated with a decreased recognition of cancer cells by cognate CD8+/Granzyme B+ T cells [43]. HLA class I down-regulation is widely recognized as a mechanism of tumor immune escape and it has been associated to cancer immunotherapy resistance [44]. In BCC, HLA class I antigen down-regulation is associated with a paucity of infiltrating CD8+ T cells [45]. Our data are 
in line with these findings. In addition, we did not detect $\beta 2-\mathrm{m}$ expression in BCC cells. $\beta 2-\mathrm{m}$ plays a crucial role in HLA class I antigen expression [46]. No epigenetic alterations have been described for $\beta 2-\mathrm{m}$. Therefore a lack of $\beta 2-\mathrm{m}$ expression might reflect mutations in $\beta 2-\mathrm{m}$ genes. $\beta 2-\mathrm{m}$ truncating mutations have been documented as a mechanism of resistance to anti-PD-1 therapy in melanoma [47]. However we did not perform a genetic analysis of $\beta 2-\mathrm{m}$ and additional studies are needed to define $\beta 2-\mathrm{m}$ mutations in BCCs. We do not know whether the lack of HLA class I antigen and $\beta 2-\mathrm{m}$ expression by tumor cells reflects an escape mechanism to nivolumab of BCC cells or whether nivolumab administration has facilitated the outgrowth of dormant tumor cells not expressing HLA class I antigen expression and subjected to the selective pressure of $\mathrm{T}$ cells unleashed by nivolumab.

In some cases HLA class I expression can be restored by interferon gamma (IFN $\gamma$ ) released by infiltrating $\mathrm{T}$ cells [48]. Alterations in the IFNY pathway genes can be responsible of ICI resistance $[49,50]$, but to the best of our knowledge no information about IFN $\gamma$ pathway genes is at present available for BCCs. In the patient we have described we hypothesize that HLA class I down-regulation cannot be restored by IFNY because of the association between lack of $\beta 2-\mathrm{m}$ expression and irreversible mutations of $\beta 2-\mathrm{m}$ gene. Lastly, we also showed that a $\mathrm{BCC}$ tumor is infiltrated by a higher number of negative regulatory immune cells which might also impair the activity of CD8+/ Granzyme B+ T cells [51], undermining the efficacy of PD-1 blockade. All these lines of evidence highlight the potential overlapping of different immunoescape mechanisms. Further studies are warranted in order to elucidate which alteration or spectrum of alterations might be useful to predict the response to ICI-based immunotherapy or which combination of different therapeutic agents might overcome tumor resistance. In BCC Walter et al. showed that the treatment with imiquimod, a toll-like receptor-7 agonist clinically approved for BCC treatment, enhanced HLA class I antigen expression and CD8+ T cell infiltration [45]. Similarly, Otsuka et al demonstrated that the administration of a SHH inhibitor up-regulated HLA class I antigen expression on BCC cells as well as infiltration of CD4+, HLA-DR-class II, and CD8+ cells [52]. These results all together provide the rationale to test combinatorial strategies including ICIs in combination with other immunomodulatory agents and/or targeted agents for BCC treatment.

\section{Conclusion}

Immunotherapy with ICIs is completely revolutionizing the clinical approach to patients with different types of malignancies such as melanoma, NSCLC, renal cell carcinoma, head and neck squamous cell carcinoma, and microsatellite instability-high and mismatch repair-deficient cancers. In addition, several immunotherapeutic agents, alone or in combination, are curently being investigated in other types of solid tumors. In the patient we have described, treatment with anti-PD-1 nivolumab did not inhibit BCC development and relapse. This lack of clinical efficacy was associated with a "cold" tumor microenvironment characterized by the lack of HLA class I antigen subunit expression, low PD-L1 expression and a high regulatory immune cell infiltration.

\section{Abbreviations}

BCC: Basal Cell Carcinoma; CTLA-4: Cytotoxic T Lymphocyte Antigen-4; H\&E: Hematoxylin and Eosin; HLA: Human Leukocyte Antigen; ICl: Immune Checkpoint Inhibitor; IHC: Immunohistochemical; mAb: monoclonal antibody; NSCLS: Non-Small Cell Lung Cancer; OS: Overall Survival; PD: Progressive Disease; PD-1: Programmed Death-1; PD-L1: Programmed Death-Ligand 1; PFS: Progression Free Survival; PR: Partial Response; PS: Performance Status; SD: Stable Disease; SHH: Sonic Hedgehog Homolog; TMB: Tumor Mutational Burden; $\beta 2 \mathrm{~m}$ : $\beta 2$-microglobulin

\section{Acknowledgements}

The authors wish to gratefully acknowledge the patient and her family for allowing us to publish her clinical case.

\section{Funding}

Not applicable.

\section{Availability of data and materials}

The data analyzed for this case report are available from the corresponding author on reasonable request.

\section{Authors' contributions}

All authors read and approved the final manuscript.

Ethics approval and consent to participate

Not applicable.

\section{Consent for publication}

Informed consent by the patient.

\section{Competing interests}

The authors declare that they have no competing interests.

\section{Publisher's Note}

Springer Nature remains neutral with regard to jurisdictional claims in published maps and institutional affiliations.

\section{Author details}

${ }^{1}$ Medical Oncology Unit, Department of Medicine, Surgery and Dentistry, University of Salerno, 84131 Salerno, Italy. ${ }^{2}$ Medical Oncology Unit, ASST Santi Paolo e Carlo, University of Milan, Milan, Italy. ${ }^{3}$ Department of Pathology, Istituto Nazionale Tumori - IRCCS- Fondazione G. Pascale, Naples, Italy. ${ }^{4}$ Department of Surgery, Massachusetts General Hospital, Harvard Medical School, Boston, MA, USA.

Received: 30 April 2018 Accepted: 31 October 2018

Published online: 20 November 2018

References

1. Ferlay J, Soerjomataram I, Dikshit R, Eser S, Mathers C, Rebelo M, Parkin DM, Forman D, Bray F. Cancer incidence and mortality worldwide: sources, methods and major patterns in GLOBOCAN 2012. Int J Cancer. 2015;136: E359-86.

2. Siegel RL, Miller KD, Jemal A. Cancer statistics, 2018. CA Cancer J Clin. 2018; 68:7-30.

3. Rubin Al, Chen EH, Ratner D. Basal-cell carcinoma. N Engl J Med. 2005;353: 2262-9. 
4. Lear W, Dahlke E, Murray CA. Basal cell carcinoma: review of epidemiology, pathogenesis, and associated risk factors. J Cutan Med Surg. 2007;11:19-30.

5. Otsuka A, Levesque MP, Dummer R, Kabashima K. Hedgehog signaling in basal cell carcinoma. J Dermatol Sci. 2015;78:95-100.

6. Bakshi A, Chaudhary SC, Rana M, Elmets CA, Athar M. Basal cell carcinoma pathogenesis and therapy involving hedgehog signaling and beyond. Mol Carcinog. 2017;56:2543-57.

7. Sekulic A, Migden MR, Oro AE, Dirix L, Lewis KD, Hainsworth JD, Solomon JA, Yoo S, Arron ST, Friedlander PA, et al. Efficacy and safety of vismodegib in advanced basal-cell carcinoma. N Engl J Med. 2012;366:2171-9.

8. Basset-Seguin N, Hauschild A, Grob JJ, Kunstfeld R, Dreno B, Mortier L, Ascierto PA, Licitra L, Dutriaux C, Thomas L, et al. Vismodegib in patients with advanced basal cell carcinoma (STEVIE): a pre-planned interim analysis of an international, open-label trial. Lancet Oncol. 2015;16:729-36.

9. Casey D, Demko S, Shord S, Zhao H, Chen H, He K, Putman A, Helms W, Keegan P, Pazdur R. FDA approval summary: Sonidegib for locally advanced basal cell carcinoma. Clin Cancer Res. 2017;23:2377-81.

10. Sharpe HJ, Pau G, Dijkgraaf GJ, Basset-Seguin N, Modrusan Z, Januario T, Tsui V, Durham AB, Dlugosz AA, Haverty PM, et al. Genomic analysis of smoothened inhibitor resistance in basal cell carcinoma. Cancer Cell. 2015;27:327-41.

11. Atwood SX, Sarin KY, Whitson RJ, Li JR, Kim G, Rezaee M, Ally MS, Kim J, Yao $C$, Chang AL, et al. Smoothened variants explain the majority of drug resistance in basal cell carcinoma. Cancer Cell. 2015;27:342-53.

12. Ribas A, Wolchok JD. Cancer immunotherapy using checkpoint blockade. Science. 2018;359:1350-5.

13. Reck M, Rabe KF. Precision diagnosis and treatment for advanced nonsmall-cell lung Cancer. N Engl J Med. 2017;377:849-61.

14. Borghaei H, Paz-Ares L, Horn L, Spigel DR, Steins M, Ready NE, Chow LQ, Vokes EE, Felip E, Holgado E, et al. Nivolumab versus docetaxel in advanced nonsquamous non-small-cell lung Cancer. N Engl J Med. 2015;373:1627-39.

15. Brahmer J, Reckamp KL, Baas P, Crino L, Eberhardt WE, Poddubskaya E, Antonia S, Pluzanski A, Vokes EE, Holgado E, et al. Nivolumab versus docetaxel in advanced squamous-cell non-small-cell lung Cancer. N Engl J Med. 2015;373:123-35.

16. Herbst RS, Baas P, Kim DW, Felip E, Perez-Gracia JL, Han JY, Molina J, Kim JH, Arvis CD, Ahn MJ, et al. Pembrolizumab versus docetaxel for previously treated, PD-L1-positive, advanced non-small-cell lung cancer (KEYNOTE-010): a randomised controlled trial. Lancet. 2016;387:1540-50.

17. Fehrenbacher L, Spira A, Ballinger M, Kowanetz M, Vansteenkiste J, Mazieres J, Park K, Smith D, Artal-Cortes A, Lewanski C, et al. Atezolizumab versus docetaxel for patients with previously treated non-small-cell lung cance (POPLAR): a multicentre, open-label, phase 2 randomised controlled trial. Lancet. 2016;387:1837-46.

18. Rittmeyer A, Barlesi F, Waterkamp D, Park K, Ciardiello F, von Pawel J, Gadgeel SM, Hida T, Kowalski DM, Dols MC, et al. Atezolizumab versus docetaxel in patients with previously treated non-small-cell lung cancer (OAK): a phase 3, open-label, multicentre randomised controlled trial. Lancet. 2017;389:255-65.

19. Reck M, Rodriguez-Abreu D, Robinson AG, Hui R, Csoszi T, Fulop A, Gottfried M, Peled N, Tafreshi A, Cuffe S, et al. Pembrolizumab versus chemotherapy for PDL1-positive non-small-cell lung Cancer. N Engl J Med. 2016;375:1823-33.

20. Garassino MC, Cho BC, Kim JH, Mazières J, Vansteenkiste J, Lena H, Corral Jaime J, Gray JE, Powderly J, Chouaid C, et al. Durvalumab as third-line or later treatment for advanced non-small-cell lung cancer (ATLANTIC): an open-label, single-arm, phase 2 study. Lancet Oncol. 2018;19:521-36.

21. Antonia SJ, Villegas A, Daniel D, Vicente D, Murakami S, Hui R, Yokoi T, Chiappori A, Lee KH, de Wit M, et al. Durvalumab after Chemoradiotherapy in stage III non-small-cell lung Cancer. N Engl J Med. 2017.

22. Ikeda S, Goodman AM, Cohen PR, Jensen TJ, Ellison CK, Frampton G, Miller $V$, Patel SP, Kurzrock R. Metastatic basal cell carcinoma with amplification of PD-L1: exceptional response to anti-PD1 therapy. NPJ Genom Med. 2016;1.

23. Lipson EJ, Lilo MT, Ogurtsova A, Esandrio J, Xu H, Brothers P, Schollenberger M, Sharfman WH, Taube JM. Basal cell carcinoma: PD-L1/PD-1 checkpoint expression and tumor regression after PD-1 blockade. J Immunother Cancer. 2017;5:23.

24. Falchook GS, Leidner R, Stankevich E, Piening B, Bifulco C, Lowy I, Fury MG. Responses of metastatic basal cell and cutaneous squamous cell carcinomas to anti-PD1 monoclonal antibody REGN2810. J Immunother Cancer. 2016:4:70.

25. Mohan SV, Kuo KY, Chang AL. Incidental regression of an advanced basal cell carcinoma after ipilimumab exposure for metastatic melanoma. JAAD Case Rep. 2016;2:13-5.
26. Goodman AM, Kato S, Cohen PR, Boichard A, Frampton G, Miller V, Stephens PJ, Daniels GA, Kurzrock R. Genomic landscape of advanced basal cell carcinoma: implications for precision treatment with targeted and immune therapies. Oncoimmunology. 2018;7:e1404217.

27. Nishino M, Ramaiya NH, Hatabu H, Hodi FS. Monitoring immune-checkpoint blockade: response evaluation and biomarker development. Nat Rev Clin Oncol. 2017; 14:655-68.

28. Fridman WH, Zitvogel L, Sautes-Fridman C, Kroemer G. The immune contexture in cancer prognosis and treatment. Nat Rev Clin Oncol. 2017;14:717-34.

29. Patel SP, Kurzrock R. PD-L1 expression as a predictive biomarker in Cancer immunotherapy. Mol Cancer Ther. 2015;14:847-56.

30. Euvrard S, Kanitakis J, Claudy A. Skin cancers after organ transplantation. N Engl J Med. 2003;348:1681-91.

31. Marra A, Scognamiglio G, Peluso I, Botti G, Fusciello C, Filippelli A, Ascierto PA, Pepe S, Sabbatino F. Immune checkpoint inhibitors in melanoma and HIV infection. Open AIDS J. 2017;11:91-100.

32. Chang J, Zhu GA, Cheung C, Li S, Kim J, Chang AL. Association between programmed death ligand 1 expression in patients with basal cell carcinomas and the number of treatment modalities. JAMA Dermatol. 2017; 153:285-90

33. Winkler JK, Schneiderbauer R, Bender C, Sedlaczek O, Frohling S, Penzel R, Enk A, Hassel JC. Anti-programmed cell death-1 therapy in nonmelanoma skin cancer. Br J Dermatol. 2017:176:498-502.

34. Rizvi NA, Hellmann MD, Snyder A, Kvistborg P, Makarov V, Havel JJ, Lee W, Yuan J, Wong P, Ho TS, et al. Cancer immunology. Mutational landscape determines sensitivity to PD-1 blockade in non-small cell lung cancer. Science. 2015;348:124-8.

35. Yarchoan M, Hopkins A, Jaffee EM. Tumor mutational burden and response rate to PD-1 inhibition. N Engl J Med. 2017;377:2500-1.

36. Hellmann MD, Ciuleanu TE, Pluzanski A, Lee JS, Otterson GA, AudigierValette C, Minenza E, Linardou H, Burgers S, Salman P, et al. Nivolumab plus Ipilimumab in lung Cancer with a high tumor mutational burden. N Engl J Med. 2018.

37. Hellmann MD, Nathanson T, Rizvi H, Creelan BC, Sanchez-Vega F, Ahuja A, Ni A, Novik JB, Mangarin LMB, Abu-Akeel M, et al. Genomic features of response to combination immunotherapy in patients with advanced nonsmall-cell lung Cancer. Cancer Cell. 2018.

38. Goodman AM, Kato S, Bazhenova L, Patel SP, Frampton GM, Miller V, Stephens PJ, Daniels GA, Kurzrock R. Tumor mutational burden as an independent predictor of response to immunotherapy in diverse cancers. Mol Cancer Ther. 2017;16:2598-608.

39. Bonilla X, Parmentier L, King B, Bezrukov F, Kaya G, Zoete V, Seplyarskiy VB, Sharpe HJ, McKee T, Letourneau A, et al. Genomic analysis identifies new drivers and progression pathways in skin basal cell carcinoma. Nat Genet. 2016;48:398-406.

40. Green MR, Monti S, Rodig SJ, Juszczynski P, Currie T, O'Donnell E, Chapuy B, Takeyama K, Neuberg D, Golub TR, et al. Integrative analysis reveals selective 9p24.1 amplification, increased PD-1 ligand expression, and further induction via JAK2 in nodular sclerosing Hodgkin lymphoma and primary mediastinal large B-cell lymphoma. Blood. 2010;116:3268-77.

41. Roemer $M G$, Advani RH, Ligon AH, Natkunam $Y$, Redd RA, Homer $H$, Connelly CF, Sun HH, Daadi SE, Freeman GJ, et al. PD-L1 and PD-L2 genetic alterations define classical Hodgkin lymphoma and predict outcome. J Clin Oncol. 2016;34:2690-7.

42. Ansell SM, Lesokhin AM, Borrello I, Halwani A, Scott EC, Gutierrez M, Schuster SJ, Millenson MM, Cattry D, Freeman GJ, et al. PD-1 blockade with nivolumab in relapsed or refractory Hodgkin's lymphoma. N Engl J Med. 2015;372:311-9.

43. Hicklin DJ, Marincola FM, Ferrone S. HLA class I antigen downregulation in human cancers: T-cell immunotherapy revives an old story. Mol Med Today. 1999;5:178-86.

44. Gettinger S, Choi J, Hastings K, Truini A, Datar I, Sowell R, Wurtz A, Dong W, Cai G, Melnick MA, et al. Impaired HLA class I antigen processing and presentation as a mechanism of acquired resistance to immune checkpoint inhibitors in lung Cancer. Cancer Discov. 2017;7:1420-35.

45. Walter A, Barysch MJ, Behnke S, Dziunycz P, Schmid B, Ritter E, Gnjatic S, Kristiansen G, Moch $H$, Knuth A, et al. Cancer-testis antigens and immunosurveillance in human cutaneous squamous cell and basal cell carcinomas. Clin Cancer Res. 2010;16:3562-70.

46. Sharma P, Hu-Lieskovan S, Wargo JA, Ribas A. Primary, adaptive, and acquired resistance to Cancer immunotherapy. Cell. 2017;168:707-23. 
47. Zaretsky JM, Garcia-Diaz A, Shin DS, Escuin-Ordinas H, Hugo W, HuLieskovan S, Torrejon DY, Abril-Rodriquez G, Sandoval S, Barthly L, et al. Mutations associated with acquired resistance to PD-1 blockade in melanoma. N Engl J Med. 2016;375:819-29.

48. Zhou F. Molecular mechanisms of IFN-gamma to up-regulate MHC class I antigen processing and presentation. Int Rev Immunol. 2009;28:239-60.

49. Gao J, Shi LZ, Zhao H, Chen J, Xiong L, He Q, Chen T, Roszik J, Bernatchez C, Woodman SE, et al. Loss of IFN-gamma pathway genes in tumor cells as a mechanism of resistance to anti-CTLA-4 therapy. Cell. 2016;167:397-404 e399.

50. Benci JL, Xu B, Qiu Y, Wu TJ, Dada H, Twyman-Saint Victor C, Cucolo L, Lee DSM, Pauken KE, Huang AC, et al. Tumor interferon signaling regulates a multigenic resistance program to immune checkpoint blockade. Cell. 2016; 167:1540-54 e1512.

51. Sasidharan Nair V, Elkord E. Immune checkpoint inhibitors in cancer therapy: a focus on T-regulatory cells. Immunol Cell Biol. 2018;96:21-33.

52. Otsuka A, Dreier J, Cheng PF, Nageli M, Lehmann H, Felderer L, Frew IJ, Matsushita S, Levesque MP, Dummer R. Hedgehog pathway inhibitors promote adaptive immune responses in basal cell carcinoma. Clin Cancer Res. 2015;21:1289-97.

53. Stam NJ, Spits H, Ploegh HL. Monoclonal antibodies raised against denatured HLA-B locus heavy chains permit biochemical characterization of certain HLA-C locus products. J Immunol. 1986;137:2299-306.

54. Sernee MF, Ploegh HL, Schust DJ. Why certain antibodies cross-react with HLA-A and HLA-G: epitope mapping of two common MHC class I reagents. Mol Immunol. 1998;35:177-88.

55. Perosa F, Luccarelli G, Prete M, Favoino E, Ferrone S, Dammacco F. Beta 2microglobulin-free HLA class I heavy chain epitope mimicry by monoclonal antibody HC-10-specific peptide. J Immunol. 2003;171:1918-26.

56. Ogino T, Bandoh N, Hayashi T, Miyokawa N, Harabuchi Y, Ferrone S. Association of tapasin and HLA class I antigen down-regulation in primary maxillary sinus squamous cell carcinoma lesions with reduced survival of patients. Clin Cancer Res. 2003;9:4043-51.

57. Pellegrino MA, Ng AK, Russo C, Ferrone S. Heterogeneous distribution of the determinants defined by monoclonal antibodies on HLA-A and B antigens bearing molecules. Transplantation. 1982:34:18-23.

58. Phillips T, Simmons P, Inzunza HD, Cogswell J, Novotny J Jr, Taylor C, Zhang X. Development of an automated PD-L1 immunohistochemistry (IHC) assay for non-small cell lung cancer. Appl Immunohistochem Mol Morphol. 2015;23:541-9.

Ready to submit your research? Choose BMC and benefit from:

- fast, convenient online submission

- thorough peer review by experienced researchers in your field

- rapid publication on acceptance

- support for research data, including large and complex data types

- gold Open Access which fosters wider collaboration and increased citations

- maximum visibility for your research: over $100 \mathrm{M}$ website views per year

At $\mathrm{BMC}$, research is always in progress.

Learn more biomedcentral.com/submissions 